\title{
Family Satisfaction of Covid-19 Patients with the Information Delivery Process and Hospital Services
}

\author{
Heru Noor Ramadhan'1, Angilian Budi Ardhianto ${ }^{1}$, Elly Yuliastuti ${ }^{1}$, Tujo Tujo ${ }^{1}$ \\ Amin Husni², Retnaningsih Retnaningsih ${ }^{2}$ \\ 1 Intensive Nursing Department, RSUP Dr. Kariadi \\ 2 Neurology Departement, RSUP Dr. Kariadi
}

\begin{tabular}{|c|c|}
\hline Article Info & Abstract \\
\hline $\begin{array}{l}\text { Article History: } \\
\text { Submitted: April 28th }, 2021 \\
\text { Accepted: June 29th, } 2021 \\
\text { Published: August 31 } \\
\text { st }, 2021 \\
\text { Keywords: } \\
\text { Family Satisfaction; Covid- } \\
\text { 19; Hospital Services; } \\
\text { Information Delivery } \\
\text { Process }\end{array}$ & $\begin{array}{l}\text { Patients /Family patients satisfaction is an indicator to assess the quality of } \\
\text { a hospital. During the Covid-19 pandemic, several problems emerged related } \\
\text { to the quality of information provision and services provided. The purpose } \\
\text { of this study was to describe the family satisfaction of Covid-19 patients with } \\
\text { the provision of information and services provided. This research is a } \\
\text { quantitative observational descriptive study with a variable of family } \\
\text { satisfaction of covid-19 patients with the information and services provided. } \\
\text { The population in this study is the families (husband / wife) of patients who } \\
\text { recovered and were treated in the Covid-19 Isolation Ward RSUP dr. Kariadi } \\
\text { Semarang with totaling } 40 \text { people. Sampling was done by using purposive } \\
\text { sampling technique and the resulting sample was } 30 \text { respondents. } \\
\text { Measurement of variables using a questionnaire providing information and } \\
\text { service delivery. The results showed that the average patient's family } \\
\text { expressed satisfaction with the provision of information ( }>30) \text { and services } \\
\text { provided (>42). Innovation is needed to further improve service quality so } \\
\text { that service quality will be even better. }\end{array}$ \\
\hline
\end{tabular}

\section{PENDAHULUAN}

Pembangunan di bidang kesehatan dewasa ini selain bertujuan untuk penyembuhan dan pemulihan juga untuk meningkatkan kesehatan dan mencegah timbulnya suatu penyakit di masyarakat. Pemerintah maupun pihak swasta yang berkecimpung dalam bidang kesehatan hendaknya memberikan perhatian khusus pada masyarakat ekonomi bawah, anak-anak dan orang lanjut usia yang ada di seluruh Indonesia sehingga pelayanan kesehatan

Corresponding author:

Elly Yuliastuti

elwied@gmail.com

Media Keperawatan Indonesia, Vol 4 No 3, August 2021

e-ISSN: 2615-1669

ISSN: 2722-2802

DOI: $10.26714 / \mathrm{mki} .4 .3 .2021 .175-181$ dapat dirasakan dengan baik dan merata [1]. Rumah sakit merupakan tempat penyediaan layanan kesehatan untuk masyarakat. Menurut Keputusan Menteri Kesehatan Republik Indonesia Nomor 983. MENKES/ SK/ 1992 mengenai pedoman rumah sakit umum dinyatakan bahwa rumah sakit umum adalah rumah sakit yang memberikan pelayanan kesehatan yang bersifat dasar, spesialistik, pendidikan dan pelatihan tenaga kesehatan [2]. Tujuan pengaturan penyelenggaraan rumah sakit salah satunya adalah meningkatkan mutu 
dan mempertahankan standar pelayanan rumah sakit [3]. Hal ini diupayakan agar seluruh masyarakat mendapatkan pelayanan kesehatan secara baik dan merata.

Tingkat kepuasan pelanggan terhadap pelayanan merupakan salah satu indikator penting dalam mengukur untuk mengembangkan suatu sistem penyediaan pelayanan yang tanggap terhadap kebutuhan pelanggan, meminimalkan biaya dan waktu serta memaksimalkan dampak pelayanan terhadap populasi sasaran [4]. Kepuasan pasien menjadi bagian yang integral dan menyeluruh dari kegiatan layanan kesehatan, artinya pengukuran tingkat kepuasan pasien menjadi kegiatan yang tidak dapat dipisahkan dari layanan kesehatan. Kepuasan pasien dalam menggunakan jasa rumah sakit merupakan cerminan hasil dari mutu [5]. Kepuasan pelaanggan akan meningkatkan kepercayaan pelanggan dan meningkatkan tingkat kunjungan ulang sehingga pendapatan suatu penyedia layanan akan meningkat juga, sebaliknya jika kepuasan pelanggan rendah maka akan membuat citra penyedia layanan buruk dan tingkat kunjungan akan menurun [6]. Penelitian menunjukan bahwa tingkat kepuasan pelanggan akan meningkatkan kunjungan ulang $[7,8]$. Penelitian tersebut didukung penelitian lain yang juga menyatakan kepuasan pelanggan akan meningkatkan tingkat kunjungan ulang dan meningkatkan pendapatan suatu layanan kesehatan $[7,9]$.

Kepuasan pelanggan berhubungan dengan kualitas pelayanan yang diberikan [8]. Pelayanan tersebut dapat berupa interaksi dengan pelayanan medis, pasien, sistem pelayanan kesehatan secara keseleruhan seperti adiminitrasi, keuangan, pelayanan informasi obat, waktu tunggu obat, serta tenaga kesehatan [10]. Oleh karena itu kepuasan pelanggan adalah output dari kualitas pelayananan yang diberikan [11]. Kualitas pelayanan merupakan keunggulan bersaing yang utama dan perlu disadari bahwa kepuasan pelanggan merupakan aspek vital dalam kelangsungan hidup rumah sakit dan dalam memenangkan persaingan. Penelitain menyebutkan bahwa semua aspek pada kualitas pelayanan yakni reliabilitas, responsivitas, empati, jaminan, dan bukti fisik memiliki pengaruh terhadap kepuasan pasien dan parameter yang paling penting untuk menilai kualitas pelayanan yang disediakan oleh penyedia layanan kepada pelanggan adalah kepuasan pelanggan [12]. Penelitian lain juga menyebutkan hal serupa bahwa kualitas pelayanan berdampak pada kepuasan pelanggan dimana kualitas pelayanan yang diteliti meliputi tangible, reliability, responsiveness, assurance, emphaty $[13,14]$. Penelitian yang dilakukan oleh [14] juga menyebutkan bahwa ada hubungan antara kualitas pelayanan keperawatan dengan kepuasan keluarga pasien. Kualitas pelayanan harus dijaga dan dipertahankan untuk menjaga customer tetap memilih penyedia layanan. Jika kualitas pelayanan turun maka akan mempengaruhi pelanggan untuk datang kembali dan memilih layanan yang lain, tentu hal ini tidak baik untuk profit bagi penyedia layanan [15]. Faktorfaktor yang menyebabkan turunnya pelayanan antara lain tidak ramahnya penyedia, kurang responsif dan tidak menyediakan tangible yang menarik baik dari kebersihan dan tampilan [5].

Pandemi Covid-19 menyebabkan penurunan angka kunjungan pasien di rumah sakit, hal ini terjadi karena terdapat alur proses pelayanan kesehatan yang berubah, pembatasan jumlah pasien sebagai upaya menghindari kerumunan, serta diterapkannya langkah pencegahan standar, identifikasi awal dan pengendalian sumber virus. Pembatasan jumlah pasien setiap harinya mengakibatkan pasien diduga berobat ke rumah sakit lain sehingga mengakibatkan penurunan jumlah pasien [16]. Data menunjukan adanya penurunan jumlah kunjungan pasien yang signifikan disejumlah rumah sakit di Jawa Barat dan Jawa Tengah [17]. Peningkatan kasus covid19 ini harus menjadikan rumah sakit meningkatkan kualitas pelayanananya, 
khususnya terhadap keluarga pasien agar tidak terjadi hal-hal yang dapat merusak citra rumah sakit dan menjadi cerita rakyat yang akan berakibat pada ketidakpercayaan publik terhadap layanan kesehatan, tentu saja hal yang perlu dievaluasi adalah pemberian informasi dan pelayanan [18].

Studi pendahuluan yang diilakukan terhadap keluarga pasien Coivd-19 menyebutkan keluarga yang sudah selesai diberikan informasi, tidak diijinkan menunggu di lingkungan rumah sakit seperti kasus pasien lain, namun dipersilakan pulang. Perawat juga memberikan bagaimana cara akses komunikasi kepada keluarga jika sewaktuwaktu ingin menguhubungi rumah sakit via telepon. Panduan tertulis mengenai proses pemberian informasi pada keluarga pasien Covid-19 belum ada, sehingga beberapa kali terjadi kesalahpahaman keluarga terkait informasi dan pelayanan yang diberikan.

Tujuan penelitian ini adalah untuk mengetahui kepuasan keluarga terhadap proses pemberian informasi dan pelayanan pasien Covid-19.

\section{METODE}

Penelitian ini merupakan penelitian kuantitatif non eksperimental dengan rancangan deskriptif observasional. Rancangan penelitian deskriptif observasional merupakan penelitian yang bertujuan untuk mendeskripsikan suatu peristiwa. Penelitian dilakukan melihat tingkat kepuasan keluarga (suami/isteri) terhadap proses pemberian informasi dan pelayanan pada pasien Covid-19 di ICU Isolasi RSUP Dr. Kariadi..

Populasi dalam penelitian ini adalah keluarga pasien (suami/isteri) yang sembuh setelah mendapatkan perawatan di ruang isolasi Covid-19 RSUP Dr. Kariadi Semarang di bulan Mei - Juni 2020 sebanyak 40 keluarga pasien. Penelitian ini sampel diambil dengan teknik purposive sampling dan didapatkan sampel sebanyak
30 responden. Tempat penelitian pada penelitian ini adalah di Ruang Isolasi RSUP Dr. Kariadi Semarang. Penelitian ini dilakukan dalam jangka waktu 2 bulan yakni bulan Juli - Agustus 2020 .

Pengumpulan data dilakukan dengan cara menggunakan kusioner. Dalam penelitian ini terdiri dari kuesioner pemberian informasi dan kuesioner pelayanan terhadap pasien Covid-19. Sumber data dalam penelitian ini merupakan data primer, yaitu data yang diperoleh dari kuesioner yang diisi secara langsung oleh responden. Apresiasi terhadap responden adalah memberikan cendera mata berupa mug.

Langkah-langkah yang dilakukan peneliti dalam pengumpulan data terbagi menjadi prosedur administratif dan prisedur teknis. Prosedur administrative dalam penelitian ini adalah: (1) Mengajukan permohonan ethical clearance kepada Komisi Etik RSUP Dr. Kariadi Semarang; (2) Mengajukan permohonan izin penelitian di bagian diklat RSUP Dr. Kariadi Semarang. (3) Mengajukan permohonan izin penelitian kepada Kepala Instalasi Rawat Intensif dan Kepala Instalasi Rajawali RSUP Dr. Kariadi Semarang. Proserdur teknisnya adalah: (1) Memilih responden berdasar kriteria inklusi; (2) Menjelaskan tujuan, manfaat, dan cara pengumpulan data kepada calon responden; (3) Memberikan lembar permohonan dan persetujuan untuk menjadi responden; (4) Mengumpulkan dan memeriksa kembali kelengkapan isian kuesioner dari responden; (5) Melakukan pengolahan dan analisis data.

Penelitian dilakukan setelah mendapatkan ijin persetujuan etik (ethical clearance) dari KEPK RSUP Dr. Kariadi Semarang dengan No.568/EC/KEPK-RSDK/2020 yang di keluarkan oleh KEPK RSUP dr. Kariadi Semarang tanggal 13 Juni 2020. Setelah surat laik etik diterima, peneliti memilah responden sesuai kriteria inklusi. Prosedur selanjutnya memberikan informed consent pada responden yang terpilih dalam riset. 
Riset di awali dengan menerangkan prosedur riset terlebih dulu. Prinsip etik lain juga diterapkan dalam penelitian ini seperti anonimity.

Penentuan puas dan tidak puasnya pemberian informasi serta pelayanan sama-sama menggunakan skor median yaitu masing-masing 30 dan 42. Peneliti melakukan analisa distribusi frekuensi berupa rerata, minimal, maksimal serta selisih untuk mengetahui gambaran kepuasan pemberian informasi dan pelayanan pasien covid-19 di Ruang Isolasi Covid-19 RSUP dr. Kariadi Semarang.

\section{HASIL}

Hasil penelitian menunjukan bahwa tingkat kepuasan suami/isteri pasien Covid-19 yang telah selesai menjalani perawatan rata-rata adalah puas dengan informasi dan pelayanan yang diberikan. Berikut adalah distribusi frekuensi kepuasan pemberian informasi dan pelayanan pada pasien covid19 di RSUP dr. Kariadi Semarang.

Tabel 1

Tingkat Kepuasan Keluarga (Suami/Isteri) terhadap Proses Pemberian Informasi dan Pelayanan pada Pasien Covid-19

\begin{tabular}{lcc}
\hline Indikator & $\begin{array}{c}\text { Kepuasan } \\
\text { Pemberian } \\
\text { Informasi }\end{array}$ & $\begin{array}{c}\text { Kepuasan } \\
\text { Pemberian } \\
\text { Pelayanan }\end{array}$ \\
\hline Usia & & \\
25-34 Tahun & $43,0 \pm 5,059$ & $61,2 \pm 6,462$ \\
35-49 Tahun & $44,2 \pm 4,534$ & $61,4 \pm 7,246$ \\
50-64 Tahun & $40,1 \pm 3,628$ & $54,7 \pm 7,443$ \\
\hline Jenis Kelamin & & \\
Laki-laki & $41,7 \pm 3,072$ & $59,0 \pm 4,055$ \\
Perempuan & $42,8 \pm 5,257$ & $59,1 \pm 8,990$ \\
\hline Pendidikan & & \\
SMP & $38,0 \pm 3,346$ & $51,0 \pm 4,857$ \\
SMA & $43,4 \pm 3,886$ & $60,8 \pm 7,548$ \\
Diploma & $43,7 \pm 4,817$ & $60,4 \pm 8,321$ \\
S1 & $43,5 \pm 4,272$ & $61,1 \pm 5,44$ \\
\hline Lama Dirawat & & \\
2-7 Hari & $42,0 \pm 4,082$ & $59,5 \pm 4,921$ \\
8-14 Hari & $42,4 \pm 4,715$ & $58,7 \pm 7,267$ \\
> 14 Hari & $42,8 \pm 4,812$ & $59,2 \pm 8,545$ \\
\hline
\end{tabular}

Tabel 1 menunjukan bahwa tingkat kepuasan suami/isteri pasien Covid-19 yang telah selesai menjalani perawatan terhadap pemberian informasi rata-rata adalah puas. Kepuasan informasi dan pelayanan pada tingkat usia paling tinggi adalah diantara usia 35-49 tahun dengan rerata 44,2 \pm 4,534 dan 61,4 \pm 7,246. Tingkat kepuasan pada jenis kelamin paling tinggi adalah perempuan dengan rerata $42,8 \pm 5,257$ pada informasi dan 59,1 \pm 8,990 pada pemberian pelayanan. Tingkat pendidikan menunjukan kepuasan informasi paling tinggi adalah pada jenjang diploma dengan rerata 43,7 \pm 4,817 dan kepuasan pelayanan paling tinggi diterima pada jenjang sarjana yaitu dengan rerata $61,1 \pm 5,44$. Lamanya perawatan yang diterima selama $>14$ hari menunjukan kepuasan informasi yang paling tinggi yaitu dengan rerata 42,8 \pm 4,812 sedangkan kepuasan pelayanan paling tinggi adalah pada masa perawatan 2-7 hari.

\section{PEMBAHASAN}

Kepuasan pemberian informasi dan pelayanan di RSUP dr. Kariadi Semarang rata-rata adalah puas. Indikator usia mempengaruhi daya tangkap seseorang dengan informasi yang diterima. Semakin bertambahnya usia maka akan semakin dewasa dan mengerti tentang informasi apa saja yang diterimanya [19]. Jenis kelamin juga merupakan faktor internal dimana seseorang mampu menyerap informasi yang diterima, biasanya perempuan akan lebih teliti dengan informasi-informasi yang diterimanya [8]. Semakin tinggi pendidikan yang diterima maka kemampuan menyerap informasi dan menilai pelayanan yang diberikan juga akan semakin obyektif, hal tersebut sesuai dengan penelitian yang menyebutkan semakin tinggi pendidikan maka akan semakin baik dalam menerima informasi dan memberikan penilaian terhadap suatu pelayanan $[7,13,20]$.

Kepuasan pada pemberian informasi ditunjukan dengan dokter mempunyai kemampuan dan pengetahuan dalam melakukan rencana tindakan, sehingga mampu menjawab setiap pertanyaan keluarga pasien secara menyakinkan, 
tenaga medis selalu memberikan informasi kondisi pasien sehingga keluarga pasien merasa tenang dan memberikan informasi tentang perkembangan kondisi pasien setiap hari. Memberikan keyakinan kepada pelanggan adalah sama dengan menunjukan suatu bentuk kualitas pelayanan. Pelanggan akan merasa tertarik dan yakin terhadap suatu produk sehingga keyakinan merupakan salah satu faktor yang mempengaruhi kepuasan [21,22]. Teori tersebut didukung oleh penelitian Kusuma 2017 yang menyebutkan keyakinan seorang apoteker dalam menjelaskan cara meminum obat kepada pasien berdampak pada kepuasan pasien [23].

Kepuasan pada pemberian pelayanan ditunjukan dengan bukti fisik yang dimiliki oleh Ruang Isolasi Pasien Covid-19 di RSUP Dr. Kariadi Semarang mendapatkan penilaian yang tinggi terhadap penampilan tenaga medis, kondisi gedung, dan kerapian ruang. Hal tersebut sesuai dengan teori Kotler bahwa tampilan fisik perusahaan, pegawai, merupakan hal yang mempengaruhi kepuasan konsumen [24]. Teori tersebut didukung penelitian yang menyatakan bahwa kualitas fisik sangat berpengaruh terhadap kualitas pelayanan dan menjadi kepuasan tersendiri bagi konsumen $[14,23,25]$.

Kepuasan juga dipengaruhi oleh keandalan tenaga medis dalam membantu keluarga pasien jika ada permasalahan. Hal tersebut sesuai dengan teori Kotler bahwasanya kemampuan dalam memberikan pelayanan harus akurat dan andal, dengan demikian konsumen akan merasa senang dan semakin percaya terhadap pelayanan yang diberikan [24]. Hal tersebut didukung oleh penelitian Kurnia pada tahun 2018 bahwa keandalan dalam suatu pelayanan akan berdampak pada kepuasan pelanggan [19]. Penelitian lain yang mendukung adalah penelitian Yulianingsih tahun 2017 yang menyebutkan bahwa semakin tingginya kepuasan maka akan semakin loyal pelanggan tersebut [23].
Perlu adanya peningkatan kepedulian dari tenaga medis dalam menanggapi keluhan pasien dan keluarga, dibuktikan dengan adanya pernyataan tenaga medis bersedia menanggapi keluhan pasien dan keluarga. Hasil tersebut didukung oleh teori Kotler bahwa respon yang cepat akan memberikan kepuasan. Cepatnya respon akan memberikan dampak konsumen merasa dipedulikan dan diperhatikan [21]. Penelitian menunjukan adanya respon yang cepat memberikan kepuasan bagi pelanggan [20,24]. Penelitian lain yang mendukung adalah penelitian dari Putri tahun 2017 bahwa adanya respon yang cepat akan memberikan dampak pelanggan untuk kembali lagi datang untuk menerima jasa pelayanan [26].

Empati harus dilakukan dengan sepenuh hati tanpa membeda-bedakan pasien satu sama lain. Wujud empati tercermin dalam perilaku tenaga medis, modal tenaga medis terletak pada keramahan dan kesabaran dan tujuannya adalah untuk meringankan beban pasien maupun keluarga pasien sehingga perasaan pasien maupun keluarga pasien jauh lebih Puas dari sebelumnya, menekankan bahwa mereka (antara pasien, keluarga pasien, dan tenaga medis) akan bersama melalui segala sesuatunya demi kesembuhan pasien kritis. Tenaga medis dengan senyum, salam, sapa serta sopan santunnya bisa membantu keluarga pasien untuk selalu tenang dan sabar sehingga mereka selalu mempunyai semangat untuk menemani keluarganya yang sedang sakit kritis [13]. Penelitian menunjukan adanya care/empathy terhadap pelanggan menunjukan pelanggan merasa puas karena dipedulikan dan direspon [14,15,23-25]

Berbagai faktor dapat mempengaruhi kepuasan pasien, maka untuk itu sangatlah penting bagi sebuah rumah sakit untuk menganalisa tingkat kepuasan pasiennya. Analisa terhadap kepuasan pasien akan sangat bermanfaat sekali bagi sebuah rumah sakit. Mengukur kepuasan pasien dapat digunakan sebagai alat untuk; 1) evaluasi kualitas pelayanan, 2) evaluasi 
terhadap konsultasi intervensi dan hubunganantara perilaku sehat dan sakit, 3) membuat keputusan administrasi, 4) evaluasi efek dari perubahan organisasi pelayanan, 5) administrasi staff, 6) fungsi pemasaran, 7) formasi etik professional. Kualitas pelayanan merupakan keunggulan bersaing yang utama dan perlu disadari bahwa kepuasan pasien merupakan aspek vital dalam kelangsungan hidup rumah sakit dan dalam memenangkan persaingan. Hasil penelitian ini sejalan dengan hasil penelitian lain yang menyatakan bahwa semua aspek pada kualitas pelayanan yakni reliabilitas, responsivitas, empati, jaminan, dan bukti fisik memiliki pengaruh terhadap kepuasan pasien. Parameter yang paling penting untuk menilai kualitas pelayanan yang disediakan oleh penyedia layanan kepada pelanggan adalah kepuasan pelanggan [1].

\section{SIMPULAN}

Rata-rata keluarga pasien covid-19 menyatakan puas terhadap pemberian informasi dan pelayanan yang diberikan oleh RSUP dr. Kariadi Semarang.

\section{UCAPAN TERIMA KASIH}

Terima kasih yang setulus-tulusnya kepada responden yang telah bersedia meluangkan waktu untuk memberikan penilaian yang sangat obyektif terhadap pemberian informasi dan pelayanan yang diberikan serta teman-teman sejawat yang sudah membantu dalam proses penelitian ini.

\section{REFERENSI}

[1] Suratri MAL, Suryati T, Edwin VA. Kepuasan Pasien terhadap Kualitas Pelayanan Pasien Rawat jalan Rumah Sakit di 7 Provinsi di Indonesia. Bul Penelit Kesehat 2018;46:23946.

[2] Riski AK. Tingkat Kepuasan Pasien pada Pelayanan Keperawatan di Rumah Sakit. J Pendidik Kesehat 2015;4:83-90.

[3] DPR RI. Undang-Undang No.44/2009 tentang Rumah Sakit. Indonesia: 2009.

[4] Kaporina. Gambaran Tingkat Kepuasan Pasien
Terhadap Pelayanan di Instalasi Rawat Inap Ruang B2 THT \& Kulit Kelamin RSUP Dr. Kariadi Semarang.Semarang: Prosiding Konferensi Nasional PPNI Jawa Tengah 2013.

[5] Salamah U, Purwanti E, ... Gambaran Tingkat Kepuasan Keluarga Pasien Terhadap Pelayanan Di Igd Rs Pku Muhammadiyah Gombong. Proceeding ... 2020:205-12.

[6] Hikmat R, Fazriah M. Hubungan antara Kepuasan Pasien dengan Minat Kunjungan Ulang 2014:645-53.

[7] Rahmiati R, Temesveri NA. Hubungan Dimensi Kualitas Pelayanan Dengan Minat Kunjungan Ulang Pasien Di Instalasi Rawat Jalan Rumah Sakit Umum Kabupaten Tangerang Tahun 2019. J Kesehat 2020;13:13-21. https://doi.org/10.23917/jk.v13i1.11097.

[8] Prastiwi EN, Ayubi D. Association Between Out of Pocket Patient's Satisfaction and Repurchase Intention at Wisma Jaya's Community Health Centre, Municipality of Bekasi, 2007. Makara J Heal Res 2015;12:42-6. https://doi.org/10.7454/msk.v12i1.288.

[9] Sukiswo SS. Hubungan Kepuasan Pasien Dengan Minat Kunjungan Ulang Di Puskesmas Sangkalan Kecamatan Susoh Kabupaten Aceh Barat. J-Kesmas J Fak Kesehat Masy (The Indones J Public Heal 2018;5:12. https://doi.org/10.35308/j-kesmas.v5i1.1144.

[10] Oktawilova L, NoriWirahmi N, Maiyulis M. Tingkat Kepuasan Pasien Rawat Jalan Terhadap Pemberian Informasi Obat (Pio) Diinstalasi Farmasi Rawat Jalan RSUD Curup Rejang Lebong. J Vokasi Keperawatan 2020;2:133-40. https://doi.org/10.33369/jvk.v2i2.10692.

[11] Chandra. Tingkat Kepuasan Keluarga Pasien Pengguna Program Badan Penyelenggara Jaminan Sosial (BPJS) Terhadap Kualitas Pelayanan Perawatan Pasien Instalasi Rawat Intensif (IRIN) Di RSUP Dr. Kariadi Semarang. E-Print Undip 2015.

[12] Kauser A. Client Satisfaction towards Quality of Health Services: An Assessment at Primary Healthcare of District Gujranwala. Int J Public Heal Sci 2017;6.

[13] Elvita Chandra Pranata JLP. Tingkat Kepuasan Keluarga Pasien Pengguna Program Badan Penyelenggara Jaminan Sosial ( BPJS ) terhadap Kualitas Pelayanan Perawatan Pasien. J Kesehat Masy 2015;4:659-68.

[14] Retnaningsih D. Kepuasan Keluarga Pasien Di Ruang Icu Rumah Sakit Permata Medika Semarang. J Kesehat Kusuma Husada 2017;8.

[15] Sulistyawati NM. Kepuasan Pelanggan Restoran Indus. E- J Manaj Unud 2015;4:2318-32.

[16] BNPB. Covid-19 Update. Badan Nas

Elly Yuliastuti / Family Satisfaction of Covid-19 Patients with the Information Delivery Process and Hospital Services 
Penanggulangan Bencana Gugus Tugas Covid192020.

[17] Susilo A, Rumende CM, Pitoyo CW, Santoso WD, Yulianti M, Herikurniawan $\mathrm{H}$, et al. Coronavirus Disease 2019: Tinjauan Literatur Terkini. J Penyakit Dalam Indones 2020;7:45. https://doi.org/10.7454/jpdi.v7i1.415.

[18] Widya Astari D, Noviantani A, Simanjuntak R. Kepuasan Pasien terhadap Mutu Pelayanan Keperawatan di Era Pandemi Covid-19 di Rumah Sakit Mata Cicendo. J Hosp Accredit 2021;03:34-8.

[19] Kurnia IR. Kepuasan Pasien terhadap Pemberian Informasi Obat pada Pelayanan Swamedikasi di Beberapa Apotek di Wilayah Surabaya Barat. Perpust Unair 2018.

[20] Ruslim TS, Rahardjo M. Identifikasi Kepuasan Konsumen Ditinjau Dari Segi Harga Dan Kualitas Pada Restoran Abuba Steak Di Greenville. J Ilm Manaj Dan Bisnis 2016;2:5165.

[21] Kotler Philip; Kevin Keller. Manajemen Pemasaran. 13th ed. Jakarta: Erlangga; 2009.
[22] Rahmayanty, Nina. Membangun Kepuasan Pelanggan Melalui. Kualitas Pelayanan. Yogyakarta: Graha Ilmu; 2010.

[23] Kusuma YD. Pengaruh Kualitas Pelayanan dan Kepuasan Pelanggan terhadap Loyalitas Pelanggan 2017.

[24] Wibisono A, Syahril. Pengaruh Kualitas Jasa Pelayanan Terhadap Kepuasan Pelanggan. Perform " J Bisnis Akuntansi" 2016;6:32. https://doi.org/10.24929/feb.v6i2.268.

[25] Bawono, Nugraheni. Pengaruh reward dan kepuasan kerja terhadap motivasi dan kinerja perawat 2015.

[26] Putri AD, Rahayu S, Astuti T. Faktor-Faktor Yang Mempengaruhi Kepuasan Konsumen Serta Dampaknya Terhadap Minat Beli Ulang Konsumen (Studi Pada Blends Pasta \& Chocolate Cabang Unika Semarang). Dipenogoro J Manag 2017;6:1-10. 